\title{
Off the Roadmap? \\ Family Medicine's Grant Funding and Committee Representation at NIH
}

Sean C. Lucan, MD, MPH $H^{1,2,3}$

Robert L. Pbillips, Jr, MD, MSPH ${ }^{4}$

Andrew W. Bazemore, MD, MPH

'Robert Wood Johnson Clinical Scholars Program, University of Pennsylvania, Philadelphia

${ }^{2}$ Department of Family Medicine and Community Health, University of Pennsylvania, Philadelphia

${ }^{3}$ Leonard Davis Institute of Health Economics, University of Pennsylvania, Philadelphia

${ }^{4}$ Robert Graham Center, Policy Studies in Family Medicine and Primary Care, Washington, DC

\section{बim}

MORE ONLINE
www.annfammed.org

\begin{abstract}
PURPOSE Family medicine is challenged to develop its own research infrastructure and to inform and contribute to a national translational-research agenda. Toward these ends, understanding family medicine's engagement with the National Institutes of Health $(\mathrm{NIH})$ is important.
\end{abstract}

METHODS We descriptively analyzed NIH grants to family medicine from 2002 through 2006 and the current $\mathrm{NIH}$ advisory committee memberships.

RESULTS Grants (and dollars) awarded to departments of family medicine increased from 89 ( $\$ 25.6$ million) in 2002, to 154 (\$44.6 million) in 2006. These values represented only $0.20 \%$ (0.15\% for dollars) and $0.33 \%$ (0.22\% for dollars), respectively, of total $\mathrm{NIH}$ awards. Nearly $75 \%$ of family medicine grants came from just 6 of NIH's grant-funding 24 institutes and centers. Although having disproportionately fewer grant continuations (62\% vs $72 \%$ ) and $\mathrm{R}$ awards (68\% vs $74 \%$ ) - particularly R01 awards ( $53 \%$ vs $84 \%$ ) -relative to NIH grantees overall, family medicine earned proportionately more new ( $28 \%$ vs $21 \%)$ and $\mathrm{K}$ awards ( $25 \%$ vs $9 \%$ ) and had more physician principal investigators ( $52 \%$ vs $15 \%)$. Ten of the nation's 132 departments of family medicine (7.6\%) earned almost $50 \%$ of all family medicine awards. Representatives from family medicine were on $6.4 \%$ of $\mathrm{NIH}$ advisory committees $(0.38 \%$ of all members); family physicians were on $2.7 \%$ ( $0.16 \%$ of members).

CONCLUSIONS Departments of family medicine, and family physicians in particular, receive a miniscule proportion of $\mathrm{NIH}$ grant funding and have correspondingly minimal representation on standing NIH advisory committees. Family medicine's engagement at the NIH remains near well-documented historic lows, undermining family medicine's potential for translating medical knowledge into community practice, and advancing knowledge to improve health care and health for the US population as a whole.

Ann Fam Med 2008;6:534-542. DOI: 10.1370/afm.911.

It is not down in any map; true places never are.

Herman Melville

with departments of family medicine and as such will bave interpreted finding from a family medicine perspective. There are, bowever, no potential, perceived or real financial conflicts of interest for any of the authors.

\section{CORRESPONDING AUTHOR}

Sean C. Lucan, MD, MPH

Robert Wood Johnson Clinical Scholars

Program

University of Pennsylvania

423 Guardian Dr

Blockley Hall, 13th Floor

Philadelphia, PA 19104-6021

sean.lucan@uphs.upenn.edu

\section{INTRODUCTION}

$\mathrm{T}$

The family of family medicine organizations has recently stated that research is integral to the specialty of family medicine; all family physicians have a role in generating new knowledge and increasing research capacity. ${ }^{1}$ This recommendation is not new. ${ }^{2}$ Even before becoming an official US medical specialty in $1969,{ }^{3}$ the World Health Organization recommended establishing research as a foundation in the emerging discipline of family medicine. ${ }^{4}$ Yet since its inception, family medicine has struggled to develop a research base. ${ }^{5}$ After 4 decades, the specialty has still not achieved a high level of research infrastructure, ${ }^{6,7}$ involvement ${ }_{1}^{8,9}$ funding, ${ }^{10}$ productivity, ${ }_{1}^{11,12}$ or credibility. ${ }^{2,13}$ 
In contrast, family medicine has a well-developed clinical infrastructure with high productivity, boasting the second greatest number of clinicians ${ }^{14}$ and providing the highest number of health care encounters in the United States. ${ }^{15}$ Because of substantial clinical presence, family physicians may be instrumental in helping to bridge the chasm between medical knowledge and actual clinical care toward improved population health. ${ }^{16}$ Such bridging is a stated focus of the National Institutes of Health (NIH), highlighted for instance in NIH's Roadmap for Medical Research. ${ }^{17}$ In fact, Roadmap has been cited as "an immediate opportunity for family medicine to contribute to the mission of the NIH." Family medicine's clinicians, for example, might participate in Roadmap's Clinical and Translational Science Awards, ${ }^{18}$ partnering with veteran investigators, to perform practice-based research in community practices. ${ }^{16}$ By contrast, family medicine's researchers could potentially lead some of these efforts. ${ }^{7,13}$

Unfortunately, though, neither family medicine's clinicians nor its researchers have strong foundations in these areas: family medicine has had a historically poor track record with the $\mathrm{NIH},{ }_{1}^{10}$ perhaps in part because of the NIH structure. NIH, the nation's leading source of support for biomedical research, ${ }^{19}$ comprises 20 institutes and 7 centers that focus primarily on specific organ systems, disease categories, and scientific specialties. ${ }^{20}$ Although new initiatives, such as Roadmap and Clinical and Translational Science Awards, could foster greater engagement with primary care, the research interests of family medicine may still not be well-aligned with the agendas of NIH institutes and centers - potentially to the disadvantage of family medicine research, the NIH mission, and overall population health in this country.

Because the agendas of the institutes and centers are largely set by NIH advisory committees, increasing family medicine representation on such committees provides an opportunity for greater engagement and is a goal of family medicine's leaders. ${ }^{1,6}$ Through membership, family medicine can participate in research review and help set priorities for national research spending. As a baseline, we were unable to identify any reports quantifying family medicine's membership on $\mathrm{NIH}$ advisory committees in the published literature.

Increasing funding from $\mathrm{NIH}$ is also a goal of family medicine leaders. ${ }^{1,6,13}$ Levels of funding for family medicine were reported most recently by Rabinowitz et $\mathrm{al}_{,}{ }^{21}$ but only for a single year (2003) and with no estimates of change through time. Trends in funding were assessed by Campos-Outcalt et al for the years 1984 to $1997 .{ }^{10}$ The conclusions of that study may no longer apply, because from 1998 to 2003 Congress doubled the NIH budget. ${ }^{22}$ Since 2003 no studies have evaluated trends in NIH grants to family medicine.
Our study had 2 specific aims: (1) to quantify current family medicine membership on NIH advisory committees, and (2) to assess the level and distribution of NIH grants to departments of family medicine during the past 5 years (2002 through 2006).

\section{METHODS}

This study used a cross-sectional design and was conducted by staff and a visiting scholar at the Robert Graham Center for Policy Studies. The study protocol was approved by the American Academy of Family Physicians' Institutional Review Board.

\section{NIH Grants to Family Medicine}

From the NIH Office of Extramural Research, we received data on all grants awarded to departments of family medicine from 2002 through 2006. The Office of Extramural Research (OER) provided these dataincluding grant number, award amount, fiscal year, principal investigators' degrees, and institution-in response to our Freedom of Information Act request. Although OER assured us of the accurateness and completeness of provided data, they would provide no information on unfunded applications "due to the privacy protection offered." From grant numbers, we determined application type, activity code, and the NIH institute or center. ${ }^{23} \mathrm{We}$ found values for NIH grant totals on the NIH Web site. ${ }^{24}$

Principal investigators were categorized as 1 of 4 types: physician (medical degree [MD or DO] with or without other degrees but no other doctoral degree), scientist (doctor of philosophy [PhD], doctor of science $[\mathrm{ScD}$ or DSc], or doctor of public health [DrPH] without a medical degree), physician-scientist (medical degree with additional doctoral degree), or other (no medical or other doctoral degree).

\section{Family Medicine on NIH Committees}

We established a universe and typology (Table 1) of $\mathrm{NIH}$ advisory committees from the NIH Web site. ${ }^{25} \mathrm{~A}$ high-ranking administrator in the NIH Office of Federal Advisory Committee Policy reviewed a preliminary committee list and ultimately endorsed our final spreadsheet as comprehensive and accurate.

We counted all members on Web site rosters for each chartered advisory committee in June 2007. All members with the word "family" in their listed affiliation were recorded. Internet searches were used to verify that "family" affiliations were actually to departments of family medicine and to discern between family physicians and other family medicine doctors (eg, clinicians, such as pediatricians and internists, or nonclinician researchers, such as statisticians and social scientists, with appointments in departments of family medicine). 


\begin{tabular}{|c|c|}
\hline Type & Function \\
\hline $\begin{array}{l}\text { Integrated or initial } \\
\text { review group (IRG) }\end{array}$ & $\begin{array}{l}\text { Provides the first level of peer review for grant applications } \\
\text { and contract proposals }\end{array}$ \\
\hline $\begin{array}{l}\text { Special emphasis panel } \\
\text { (SEP) }\end{array}$ & $\begin{array}{l}\text { Like IRGs, provides a first level of peer review. Unlike IRG, has } \\
\text { no standing memberships; members are designated to serve } \\
\text { for individual meetings rather than appointed for fixed terms }\end{array}$ \\
\hline $\begin{array}{l}\text { National advisory } \\
\text { council or board } \\
\text { (NAC) }\end{array}$ & $\begin{array}{l}\text { Performs the second level of peer review and offers advice on } \\
\text { policy and program development for institutes and centers } \\
\text { as well as oversight of intramural research }\end{array}$ \\
\hline $\begin{array}{l}\text { Board of scientific } \\
\text { counselors (BSC) }\end{array}$ & $\begin{array}{l}\text { Reviews and evaluates investigators and research programs of } \\
\text { intramural laboratories }\end{array}$ \\
\hline $\begin{array}{l}\text { Program advisory } \\
\text { committee (PAC) }\end{array}$ & $\begin{array}{l}\text { Provides advice on specific research programs and future } \\
\text { research needs and opportunities }\end{array}$ \\
\hline
\end{tabular}

\section{RESULTS}

\section{NIH Grants to Family Medicine}

Departments of family medicine received $\$ 187$ million from 2002 through 2006 (Table 2). This total was $0.20 \%$ of the $\$ 95.3$ billion the $\mathrm{NIH}$ awarded during that same period. About $40 \%$ of the NIH budget went to the type of applied research ${ }^{26}$ that family medicine researchers tend to perform, and family medicine's share of this lesser sum was about $0.49 \%$. The absolute number of grants (and dollars) earned by departments of family medicine increased by diminishing amounts during the 5 -year period, from a $33 \%$ increase $(48 \%$ for dollars) $2002-2003$, to a $5 \%$ increase (3\% for dollars) 2005-2006. Proportionate increases followed a similar pattern: from 25\% (35\% for dollars) 2002-2003, to $7 \%$ (3\% for dollars) 2005-2006. Family medicine received only $638(0.28 \%)$ of the more than 230,000 awards NIH made from 2002 to 2006.

The National Cancer Institute awarded more than one-quarter of all family medicine grants - more than twice the number awarded to family medicine by each of the next 2 highest funding institutes and centers (Table 2). The top 3 institutes and centers awarded nearly $50 \%$ of all grants; the top 6 awarded almost $75 \%$. In 2006, the highest and third highest granting institutes and centers were the same for family medicine and $\mathrm{NIH}$ awardees overall. But the second highest granting institute for NIH awardees overall, the National Institute of Allergy and Infectious Diseases, did not appear in the top 10 for family medicine; and the second highest granting institute for family medicine, the National Center for Complementary and Alternative Medicine, did not appear in the top 10 for NIH awardees overall. ${ }^{27}$

More than two-thirds of family medicine awards were for R grants (Table 2), of which one-half were for R01 awards (discrete projects by principal investigators). $\mathrm{K}$ awards (research career programs grants) accounted for $25 \%$ of family medicine grants. Over the 5 years, there was an increase in the proportion of $\mathrm{K}$ awards rela- tive to $\mathrm{R}$ awards for family medicine. In contrast, grant proportions for the $\mathrm{NIH}$ in general remained stable over the 5 years, with $\mathrm{R}$ awards accounting for about $75 \%$ (nearly $85 \%$ R01) and $\mathrm{K}$ awards accounting for $9 \%$ of the total. ${ }^{28}$

Physicians in family medicine were awarded more than one-half of all grants (Table 2). Two-thirds of these physician grantees had additional master's level training, and another $10 \%$ had doctoral degrees. In general the great majority of NIH grants (as much as $85 \%$ ) go to grantees with doctoral degrees. ${ }^{29}$

One-half to two-thirds of family medicine grants in any given year were noncompeting continuations (Table 2). New applications accounted for as little as one-fifth or as much as one-third of awarded family medicine grants. For NIH totals, noncompeting continuations accounted for two-thirds to three-quarters of the total (average $72 \%$ ), and new requests made up one-fifth to one-quarter (average 21\%). ${ }^{30}$

Of the 132 departments of family medicine in US medical schools, 63 (48\%) earned NIH grants in the last 5 years. Ten departments $(16 \%$ of those funded, $7.6 \%$ of the US total) accounted for almost $50 \%$ of all family medicine awards; 4 departments cumulatively earned $25 \%$ of awards, and 1 department alone earned 11\% (Table 2). From 2002 through 2006, 25 of the funded departments (40\%) received less than 1 grant per year; and $8(13 \%)$ received only 1 grant total. Three of the top-10 departments of family medicine were from the top-10 medical schools in terms of total $\mathrm{NIH}$ grants; 6 were from the top-20 schools in terms of total NIH grants. ${ }^{31}$

Distributions by awarded dollars (displayed in the Supplemental Appendix, available at http://www. annfammed.org/cgi/content/full/6/6/534/DC1) were essentially similar to distributions by numbers of grants. Notably though, 4 of the top 10 departments of family medicine by number of grants did not appear in the top 10 departments for grant dollars - mostly because of relative proportions of $\mathrm{R}$ and $\mathrm{K}$ awards, and the greater dollar amounts (generally about $250 \%$ greater) awarded for $\mathrm{R}$ grants.

In 2006, family medicine earned no awards from one-third of all grant-funding NIH institutes and centers (Table 3 ).

\section{Family Medicine Represented on NIH Committees}

The NIH listed 154 chartered advisory committees on its Web site. ${ }^{25}$ Thirteen committees were inactive 
Table 2. NIH Grants Awarded to Departments of Family Medicine From 2002 to 2006, and Distributions of Family Medicine Totals by Number of Grants

\begin{tabular}{|c|c|c|c|c|c|c|}
\hline $\begin{array}{l}\text { Family Medicine and NIH Totals and } \\
\text { Percentages }\end{array}$ & $\begin{array}{l}\text { Grants } \\
2002\end{array}$ & $\begin{array}{l}\text { Grants } \\
2003\end{array}$ & $\begin{array}{l}\text { Grants } \\
2004\end{array}$ & $\begin{array}{l}\text { Grants } \\
2005\end{array}$ & $\begin{array}{l}\text { Grants } \\
2006\end{array}$ & $\begin{array}{l}\text { Total Grants } \\
2002-2006\end{array}$ \\
\hline Family medicine total grant dollars received, $\$$ (in millions) & 25.6 & 37.9 & 34.8 & 43.5 & 44.6 & 187 \\
\hline NIH total grant dollars awarded, $\$$ (in millions) & 16,900 & 18,500 & 19,700 & 20,300 & 20,200 & 95,300 \\
\hline$\%$ of total NIH grant dollars awarded to family medicine & 0.15 & 0.21 & 0.18 & 0.22 & 0.22 & 0.20 \\
\hline Family medicine total grants received, No. & 89 & 118 & 131 & 146 & 154 & 638 \\
\hline NIH total grants awarded, No. & 43,520 & 46,081 & 47,464 & 47,345 & 46,797 & 231,207 \\
\hline$\%$ of total NIH grants awarded to family medicine & 0.20 & 0.26 & 0.28 & 0.31 & 0.33 & 0.28 \\
\hline \multicolumn{7}{|l|}{ Family medicine total received No. of grants } \\
\hline \multicolumn{7}{|l|}{ By institute or center, \% } \\
\hline $\mathrm{NCl}$ & 21 & 27 & 25 & 27 & 29 & 26 \\
\hline NCCAM & 10 & 11 & 10 & 12 & 12 & 11 \\
\hline NHLBI & 8 & 10 & 10 & 10 & 13 & 11 \\
\hline $\mathrm{NIMH}$ & 8 & 11 & 11 & 10 & 7 & 9 \\
\hline NIDA & 13 & 8 & 10 & 8 & 8 & 9 \\
\hline NIDDK & 3 & 7 & 11 & 8 & 5 & 7 \\
\hline NICHD & 6 & 7 & 5 & 6 & 7 & 6 \\
\hline NIA & 8 & 7 & 7 & 5 & 5 & 6 \\
\hline NIAAA & 9 & 3 & 5 & 5 & 5 & 5 \\
\hline NIEHS & 2 & 1 & 2 & 1 & 3 & 2 \\
\hline Other ${ }^{\mathrm{a}}$ & 11 & 8 & 5 & 7 & 8 & 8 \\
\hline \multicolumn{7}{|l|}{ By activity code, $\%$} \\
\hline $\mathrm{R}$ & 71 & 75 & 72 & 63 & 61 & 68 \\
\hline K & 21 & 19 & 24 & 29 & 29 & 25 \\
\hline Other $^{\mathrm{b}}$ & 8 & 5 & 4 & 8 & 10 & 7 \\
\hline \multicolumn{7}{|l|}{ By principal investigator type, ${ }^{c} \%$} \\
\hline Physician & 48 & 51 & 56 & 54 & 49 & 52 \\
\hline Scientist & 37 & 36 & 32 & 35 & 39 & 36 \\
\hline Physician-scientist & 12 & 9 & 11 & 10 & 9 & 10 \\
\hline Other & 2 & 4 & 2 & 1 & 3 & 2 \\
\hline \multicolumn{7}{|l|}{ By application type, \% } \\
\hline Noncompeting continuation & 65 & 54 & 63 & 61 & 68 & 62 \\
\hline New & 20 & 36 & 28 & 31 & 25 & 28 \\
\hline Other ${ }^{d}$ & 15 & 10 & 9 & 8 & 7 & 9 \\
\hline \multicolumn{7}{|l|}{ By department of family medicine, \% } \\
\hline Univ of California, San Diego & 7 & 13 & 11 & 11 & 12 & 11 \\
\hline Univ of Wisconsin & 9 & 3 & 6 & 5 & 6 & 6 \\
\hline Univ of Michigan ${ }^{f}$ & 4 & 4 & 5 & 4 & 4 & 4 \\
\hline Univ of Minnesota-Twin Cities & 6 & 5 & 4 & 3 & 4 & 4 \\
\hline Univ of Arizona & 0 & 0 & 2 & 5 & 9 & 4 \\
\hline Univ of New Mexico & 4 & 4 & 5 & 3 & 3 & 4 \\
\hline Univ of Washington ${ }^{f}$ & 4 & 3 & 5 & 4 & 2 & 4 \\
\hline Case Westerne & 4 & 3 & 4 & 3 & 3 & 3 \\
\hline Univ of Pennsylvaniaf & 1 & 5 & 3 & 3 & 4 & 3 \\
\hline Univ of North Carolina, Chapel Hille & 3 & 5 & 4 & 3 & 2 & 3 \\
\hline Other ${ }^{g}$ & 56 & 53 & 53 & 53 & 52 & 53 \\
\hline
\end{tabular}

$\mathrm{K}=$ research career programs; NCCAM = National Center for Complementary and Alternative Medicine; $\mathrm{NCl}=\mathrm{National}$ Cancer Institute; $\mathrm{NHLBI}=\mathrm{National}$ Heart Lung and Blood Institute; NIA = National Institute on Aging; NIAAA = National Institute on Alcohol Abuse and Alcoholism; NICHD = National Institute of Child Health and Human Development; NIDA = National Institute on Drug Abuse; NIDDK = National Institute of Diabetes and Digestive and Kidney Diseases; NIEHS = National Institute of Environmental health Sciences; $\mathrm{NIH}=$ National Institutes of Health; $\mathrm{NIMH}=$ National Institute of Mental Health; $\mathrm{R}=$ research projects; Univ $=$ university.

Note: Percentages are columns percentages and may not sum to $100 \%$ because of rounding error; only distributions for number of grants are presented-distributions for grant dollars were essentially similar and available in the Supplemental Appendix, available online at http://www.annfammed.org/cgi/content/full/6/6/534/DC1.

${ }^{a}$ Includes 11 institutes or centers for a total of 21 awarding grants to department of family medicine over the 5 years; ${ }^{b}$ Includes $\mathrm{U}$ (cooperative agreements), $\mathrm{P}$ (research program projects and centers), $T$ (training programs), G (resource programs), and S (research-related programs); ${ }^{c}$ Physician $=$ medical degree (MD or DO) only, scientist = doctor of philosophy (PhD), doctor of science (ScD, DSc), or doctor of public health (DrPH) only; other includes principal investigators with only bachelor's- or master's-level training, but no doctoral degrees; ${ }^{\mathrm{d}}$ Competing continuations, supplements, and change of grantee or training institution; e Department at a top-20 institution for number of $\mathrm{NIH}$ grant awards; ${ }^{\mathrm{f}}$ Department at a top-10 institution for number of $\mathrm{NIH}$ grant awards; 9 Includes 53 additional academic institutions. 
and 3 had no appointed members (Figure 1). Of the active committees, special emphasis panels (SEPs) have neither standing nor reported memberships, and individual integrated or initial review groups (IRGs) were often divided into multiple subcommittees (2 to 14). In total, there were 229 IRGs and subcommittees. Considering all active committees and subcommittees with standing members together, there were 295 groups.

Membership for the 295 groups totaled 5,464
(Figure 2). There were 21 committee members from departments of family medicine. Of these, 9 were family physicians. For the other 12, 1 was a pediatrician, 1 was an internist, and 10 had nonmedical doctoral degrees. Departments of family medicine had members on just $6.4 \%$ of all committees (and subcommittees), accounting for only $0.38 \%$ of advisory committee members. For family physicians specifically, these proportions were $2.7 \%$ and $0.16 \%$, respectively.

\section{Table 3. Distributions of Grant Funding and Advisory Committee Membership} by NIH Institutes and Centers

\begin{tabular}{|c|c|c|c|c|}
\hline \multirow[b]{2}{*}{ Institute, Center, or Office (Abbreviation) } & \multicolumn{2}{|c|}{ Grants Awarded in 2006} & \multicolumn{2}{|c|}{$\begin{array}{l}\text { No. of Advisory Committee } \\
\text { Members June } 2007 \\
\text { (Advisory Committee Type) }\end{array}$} \\
\hline & $\begin{array}{c}\% \text { of Total } \\
\text { Grants to Family } \\
\text { Medicine }\end{array}$ & $\begin{array}{c}\% \text { of Total } \\
\text { Grant Dollars to } \\
\text { Family Medicine }\end{array}$ & $\begin{array}{l}\text { Family } \\
\text { Physicians }\end{array}$ & $\begin{array}{c}\text { Other } \\
\text { Family Medicine } \\
\text { Doctors }\end{array}$ \\
\hline Clinical Center ${ }^{\mathrm{a}}$ (CC) & - & - & - & - \\
\hline Center for Information Technology ${ }^{a}$ (CIT) & - & - & - & - \\
\hline Center for Scientific Reviewa (CSR) & - & - & $4($ IRG) & 6 (IRG) \\
\hline Fogarty International Center (FIC) & 1 & 1 & - & 1 (NAC) \\
\hline $\begin{array}{l}\text { National Center for Complementary and Alternative Medicine } \\
\text { (NCCAM) }\end{array}$ & 12 & 13 & - & - \\
\hline National Cancer Institute (NCI) & 29 & 33 & - & $2(\operatorname{IRG})^{\mathrm{b}}$ \\
\hline $\begin{array}{l}\text { National Center on Minority Health and Health Disparities } \\
\text { (NCMHD) }\end{array}$ & 1 & 3 & - & - \\
\hline National Center for Research Resources (NCRR) & 2 & 2 & - & - \\
\hline National Eye Institute (NEI) & - & - & - & - \\
\hline National Human Genome Research Institute (NHGRI) & - & - & - & - \\
\hline National Heart Lung and Blood Institute (NHLBI) & 13 & 9 & - & - \\
\hline National Institute on Aging (NIA) & 5 & 4 & - & - \\
\hline National Institute on Alcohol Abuse and Alcoholism (NIAAA) & 5 & 6 & - & - \\
\hline National Institute of Allergy and Infectious Diseases (NIAID) & - & - & - & - \\
\hline $\begin{array}{l}\text { National Institute of Arthritis and Musculoskeletal and Skin } \\
\text { Diseases (NIAMS) }\end{array}$ & 1 & 2 & - & - \\
\hline $\begin{array}{l}\text { National Institute of Biomedical Imaging and Bioengineering } \\
\text { (NIBIB) }\end{array}$ & - & - & - & - \\
\hline $\begin{array}{l}\text { National Institute of Child Health and Human Development } \\
\text { (NICHD) }\end{array}$ & 7 & 3 & - & - \\
\hline National Institute on Drug Abuse (NIDA) & 8 & 6 & 1 (IRG) & 2 (IRG) \\
\hline $\begin{array}{l}\text { National Institute on Deafness and other Communication } \\
\text { Disorders (NIDCD) }\end{array}$ & - & - & - & - \\
\hline National Institute of Dental and Craniofacial Research & - & - & - & - \\
\hline $\begin{array}{l}\text { National Institute of Diabetes and Digestive and Kidney } \\
\text { Diseases (NIDDK) }\end{array}$ & 5 & 6 & - & - \\
\hline National Institute on Environmental Health Sciences (NIEHS) & 3 & 5 & - & - \\
\hline National Institute of General Medical Sciences (NIGMS) & - & - & - & - \\
\hline National Institute of Mental Health (NIMH) & 7 & 7 & 1 (IRG) & 1 (IRG) \\
\hline National Institute of Neurologic Disorders and Stroke (NINDS) & - & - & - & - \\
\hline National Institute of Nursing Research (NINR) & 1 & 0 & 1 (NAC) & - \\
\hline National Library of Medicine (NLM) & 2 & 1 & 1 (IRG) & - \\
\hline Office of the Director (OD) & - & - & 1 (PAC) & - \\
\hline Totals & 100 & 100 & $9^{c}$ & $12^{c}$ \\
\hline \multicolumn{5}{|c|}{ IRG = Integrated or initial review group; NAC = national advisory council and board; NIH = National Institutes of Health; PAC = program advisory committee. } \\
\hline \multicolumn{5}{|c|}{ Note: Percentages are columns percentages and may not sum to $100 \%$ because of rounding error; - indicates 0 values. } \\
\hline \multicolumn{5}{|l|}{ a CC, CIT, and CSR do not award grants. } \\
\hline \multicolumn{5}{|c|}{$\begin{array}{l}\text { b One family medicine member at } \mathrm{NCl} \text { was committee chair, all other family medicine members on all other committees were general members. } \\
\text { c The } 9 \text { family physician members served on } 8 \text { committees, and } 12 \text { other family medicine doctors served on } 11 \text { committees. }\end{array}$} \\
\hline
\end{tabular}


Almost $75 \%$ of the NIH institutes and centers had no family medicine input on committees, and only a minority of the NIH agencies from which family medicine received funding had family medicine committee members (Table 3 ). Almost $85 \%$ of family medicine committee involvement was on IRGs. There was only 1 committee with a family medicine-affiliated chair in all of NIH (an IRG at the National Cancer Institute).

\section{DISCUSSION}

Our study had 2 main findings. First, although absolute and proportionate funding to family medicine increased after the doubling of the NIH budget, increases have been rapidly diminishing, and absolute funding levels have remained as miniscule as they have been for more than 20 years. ${ }^{10}$ Moreover, for reasons discovered by Rabinowitz et al, the family medicine funding levels we report may overestimate, by as much as two-thirds, the money actually going to principal investigators in core family medicine organizational components. ${ }^{21}$ And although our analysis shows that physicians were consistently the group of family medicine researchers most successful in obtaining NIH grants, almost one-half of physician principal investigators may not actually be family physicians. ${ }^{21}$

Second, family medicine has minimal representation on NIH advisory committees. Stakeholders from departments of family medicine are, thus, largely disenfranchised, having few seats at the table and little say in setting the national research agenda. This lack of representation is particularly true and perhaps most ironic for family physicians, whose extensive clinical practices $^{32,33}$ and community ties make them ideally suited for advising on dissemination, implementation, and adoption of research. ${ }^{34}$

As the NIH struggles to translate the fruits of biomedical research into practice, family medicine struggles to fortify and invigorate its research capacity. A less-understood outcome of this mutual frustration is the failure to make the more than 200 million annual patient visits to family physician practices ${ }^{15}$ a source of medical discovery, new knowledge, and greater engagement between family medicine and

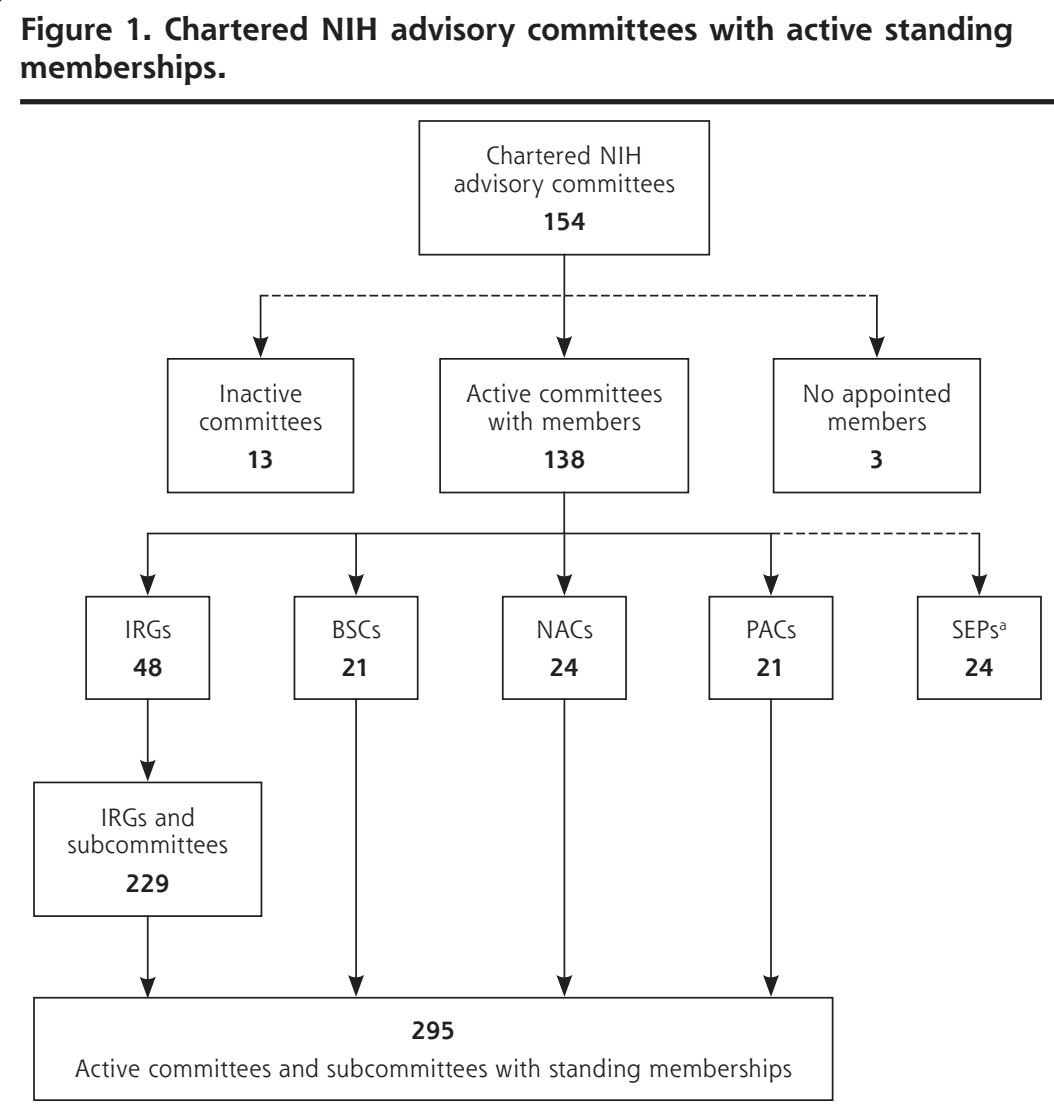

- = included groups; - - - = excluded groups; BSC = board of scientific counselors, IRG $=$ integrated or initial review group, $\mathrm{NAC}=$ national advisory council or board, $\mathrm{NIH}=$ National Institutes of Health, $\mathrm{PAC}=$ program advisory committee, SEP = special emphasis panel.

aspecial emphasis panels have no standing (or reported) memberships.
NIH. Results from our study and previous work suggest potential strategies to facilitate greater connection and mutual benefit.

One strategy focuses on committee membership, both for practicing family medicine clinicians and career family medicine investigators. Practicing family physicians could serve in public seats on NIH advisory committees, offering community experience, clinical insights, and practice perspective. The Federal Advisory Committee Act requires that membership on $\mathrm{NIH}$ advisory committees be fairly balanced in terms of points of view represented, and national advisory councils and boards and program advisory committees specifically must have one-third public members by law. ${ }^{35}$ The other two-thirds are for scientific members-such as career family medicine investigators-with established records of research success. ${ }^{35}$ Although it is unclear that greater participation on $\mathrm{NIH}$ advisory committees will result in greater funding for family medicine research, it will cer- 


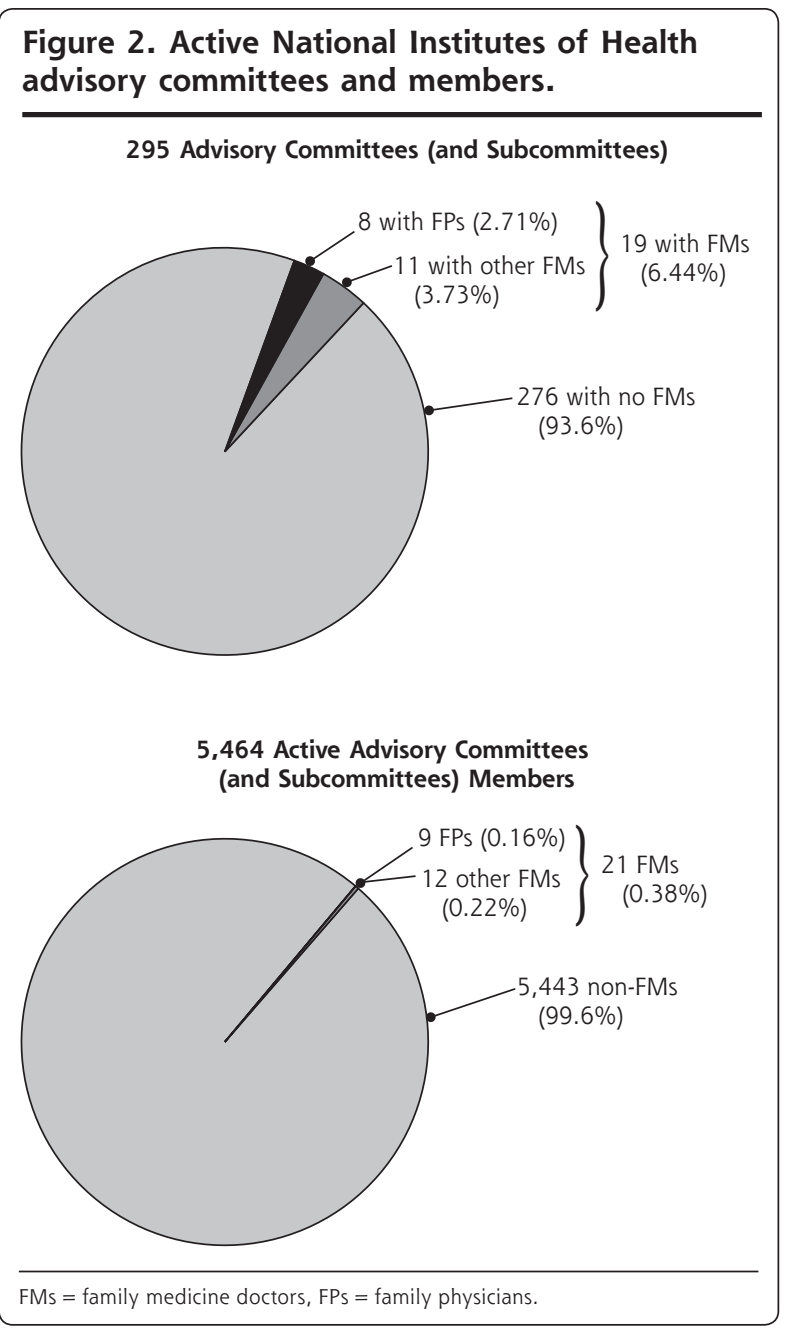

tainly give family physicians greater voice in setting national research priorities and in shaping $\mathrm{NIH}$ efforts to translate basic science discovery to front-line clinical practice. Self-nomination to advisory committees is one mechanism that makes increased membership possible. ${ }^{35}$

A second strategy is greater research training. In our data, most family physician grantees and family medicine committee members had additional advanced degrees. $\mathrm{NIH}$ and family medicine could strengthen partnerships for advanced degrees and research training through National Research Service Award expansion, greater involvement in the Howard Hughes Medical Institute, $\mathrm{NIH}$ fellowships, or novel research training programs.

A third strategy is to draw on past successes by family medicine. As shown in our study and as noted by others, ${ }^{36}$ only a select group of departments of family medicine have any substantial engagement with the NIH. Through hub-and-spoke networking, ${ }^{13}$ these sites might supply role models and teachers to bring lessons about building successful research enterprise to the larger family medicine community (perhaps even through novel programs and financial backing from the NIH). Lessons from leaders could be helpful, not only for community family medicine clinicians, ${ }^{37}$ by fostering participation in practice-based investigations and quality-improvement initiatives, but also for aspiring career family medicine investigators, ${ }^{13}$ by providing guidance on grantsmanship and counsel on doing national-level research.

A final, related, strategy involves partnerships with existing research infrastructure, both within and outside family medicine. ${ }^{2,13}$ Family physicians in community practices might develop collaborative relationships with practice-based research networks ${ }^{38}$ and academic health centers that are part of the Clinical and Translational Science Awards consortium. ${ }^{6}$ They could thereby contribute to generating new knowledge by informing research questions, ${ }_{1}^{13}$ carrying out trials, and developing ideas for new kinds of research. ${ }^{16}$ For established family medicine investigators, expanding roles as collaborators, consultants, coinvestigators, and mentors will be important. Mentoring in particular will be key as family medicine strives to increase numbers in its research vanguard, developing new talent capable of independent investigation. ${ }^{1,713}$ Burgeoning junior investigators could look to veteran grantees-preferably in family medicine but also in other disciplines-for mentoring through career development programs (ie, K awards). ${ }^{1,6,13,21}$ Encouragingly, with disproportionate percentages of new awards and $\mathrm{K}$ awards going to family medicine during the last 5 years, partnering with mentors and existing research infrastructure may already be occurring.

Our study has notable strengths. Analyses of awards over the last 5 years allowed us to appreciate that there has been little substantive change in funding to family medicine since previous analyses, specifically in relation to the doubling of the NIH budget. We also considered application type, which had not been reported previously. Data on advisory committee memberships provided additional perspective and corroboration not found in published literature.

In spite of these strengths, we must consider limitations in interpreting our results. First, we can make no comment about family medicine investigators who were collaborators or co-principal investigators, as such data were not available from NIH. This omission is important because research is increasingly interdisciplinary and networked. ${ }^{39}$ Although the ability to perform autonomous investigation has traditionally been a measure of the status and vitality of a discipline, ${ }^{29}$ research as a culture is shifting to encompass more collaborative and team-based models. ${ }^{39,40} \mathrm{NIH}$ just started collecting reliable data on co-principal investigators in 2006, and future studies should evaluate family medicine's role in collaboration. Indeed, interdisciplin- 
ary cooperation may be essential for family medicine to develop a critical mass of competent investigators. ${ }^{1,13}$

Second, there was some risk of misclassifying researchers in our data owing to family physicians working outside departments of family medicine or principal investigators having multiple departmental affiliations, for example. Rabinowitz et al reported 22 out of 149 cases (15\%) in 2003 in which family medicine researchers were actually listed under departments of public health and preventive medicine. ${ }^{21}$ Although we received assurance from Office of Extramural Research that the data provided for our study was complete and accurate, if the same level of misclassification were at play, family medicine would have actually received $0.32 \%$ of $\mathrm{NIH}$ awards from 2002 through 2006 rather than the $0.28 \%$ we report. The potential for misclassification or missed identification for advisory committee members is also a concern. Only a single affiliation for each committee member was listed; thus, any family medicine researchers using a primary, non-family medicine affiliation would have been uncounted. Conversely, any principally non-family medicine researcher using family medicine as a primary affiliation would have been captured inappropriately. Given the tiny membership percentages we report, however, even large errors would not have changed our overall findings meaningfully.

Third, we had to limit our analysis of advisory committees to those with standing memberships-that is, we had to exclude special emphasis panels. To be generous, even if we were to make the unlikely assumption that every special emphasis panel had at least 1 family medicine member, then the percentage of advisory committees with family medicine members would increase from the $6.4 \%$ we report to $13.5 \%$, and family medicine membership would rise from $0.38 \%$ of all members to $0.82 \%$. In our view, this change would not represent a meaningful difference.

Finally, we do not provide a comparison groupanother medical specialty, for instance-for our analyses. Listed affiliations on committee rosters were not sufficient to distinguish generalists from subspecialists in other specialties. Based on prior work, however, family medicine spends substantially less time on research than other primary care fields. ${ }^{1,7,41}$ In fact, according to a 2001 report, departments of family medicine receive roughly $6 \%$ as much NIH funding as do departments of pediatrics, and about $1 \%$ as much as departments of internal medicine. ${ }^{42}$ Negotiations with NIH for data comparing grant applications and success rates among specialties are ongoing by our group.

Despite limitations, we can confidently conclude from our study that family medicine is not well-engaged with the NIH and is essentially off the Roadmap. The
$\mathrm{NIH}$ director has written, "NIH needs to have an explicit and dynamic process for supporting critical scientific programs that cut across scientific areas and that none of the individual institutes could support on its own." 26 This kind of sentiment drives the Roadmap and Clinical and Translational Science Award programs and speaks directly to the integrative role of family medicine. ${ }^{36}$ At the same time, the Future of Family Medicine project and family medicine leadership have called for increasing emphasis on research ${ }^{1,13,43,44}$ and engagement with the NIH. ${ }^{1,13}$ Family medicine and the NIH have what each other wants, but the potential for greater partnership has not been realized. Lack of family medicine involvement in the planning and performance of federally funded research has implications for the direction of biomedical research in this country, its relevance to actual patient care, and its ultimate impact on public health. Lack of NIH support for family medicine investigational initiatives has implications for family medicine's research capacity and the status and vitality of the specialty. Through greater research training, collaborations, and self-advocacy, family medicine might foster a better relationship with the NIH, to the benefit of both.

To read or post commentaries in response to this article, see it online at http://www.annfammed.org/cgi/content/full/6/6/534.

Key words: National Institutes of Health; family practice; family physicians; research; advisory committees;

Submitted December 22, 2007; submitted, revised, June 25, 2008; accepted June 30, 2008.

This study has been previously presented at an invited plenary session, Association of Departments of Family Medicine, Winter Meeting, San Diego, California, February 23, 2008; and at an abstract presentation, Pennsylvania Academy of Family Physicians, Research Day, Bedford, Pennsylvania, March 8, 2008.

Disclaimer: The information and opinions contained in research from the Robert Graham Center do not necessarily reflect the views or policy of the American Academy of Family Physicians.

Acknowledgments: Special thanks to Frances K. Barg, PhD, MEd, Department of Family Medicine and Community Health, University of Pennsylvania, Philadelphia; Mark Johnson, MD, MPH, Chair, Department of Family Medicine, University of Medicine $\varepsilon$ Dentistry of New Jersey; Larry A. Green, MD, Department of Family Medicine, University of Colorado, Division of Information Services, NIH, Office of Extramural Research; Femi Olaniyan, Microsoft Excel expert.

\section{References}

1. North American Primary Care Research Group Committee on Building Research Capacity and the Academic Family Medicine Organizations Research Subcommittee. What does it mean to build research capacity? Fam Med. 2002;34(9):678-684.

2. Dickinson WP, Stange KC, Ebell MH, Ewigman BG, Green LA. Involving all family physicians and family medicine faculty members in the use and generation of new knowledge. Fam Med. 2000; $32(7): 480-490$. 
3. American Academy of Family Physicians Foundation. Center for the History of Family Medicine [Web site]. http://www.aafpfoundation. org/historycenter.xml. Accessed Sep 9, 2007.

4. Dennis S. The History of Family Medicine. http://www.aafpfoundation.org/PreBuilt/foundation_dennisresearch.pdf.

5. Mainous AG III, Hueston WJ, Ye X, Bazell C. A comparison of family medicine research in research intense and less intense institutions. Arch Fam Med. 2000;9(10):1100-1104.

6. Johnson MS, Davis A. Academic family medicine's response to CTSA. Ann Fam Med. 2007;5(3):275-277.

7. Johnson MS. The family medicine road to the NIH roadmap. Ann Fam Med. 2006;4(1):89.

8. Murata PJ, Lynch WD, Puffer JC, Green LA. Attitudes toward and experience in research among family medicine chairs. J Fam Pract. 1992;35(4):417-421.

9. Young RA, Dehaven MJ, Passmore C, Baumer JG. Research participation, protected time, and research output by family physicians in family medicine residencies. Fam Med. 2006;38(5):341-348.

10. Campos-Outcalt D, Senf J. Family medicine research funding. Fam Med. 1999;31(10):709-712.

11. Brocato JJ, Mavis B. The research productivity of faculty in family medicine departments at U.S. medical schools: a national study. Acad Med. 2005;80(3):244-252.

12. Weiss BD. Why family practice research? Arch Fam Med. 2000; 9(10):1105-1107.

13. Mainous AG III, Hueston WJ. Is family medicine ready to move toward having professional researchers? Fam Med. 2006;38(5):361-362.

14. Bureau of Labor Statistics. U.S. Department of Labor. Occupational Outlook Handbook, 2006-2007 Edition, Physicians and Surgeons. http://www.bls.gov/oco/ocos074.htm. Accessed Nov 1, 2007.

15. Cherry DK, Woodwell DA, Rechtsteiner EA. National Ambulatory Medical Care Survey: 2005 Summary-Advance data from vital and health statistics; no 387. http://www.cdc.gov/nchs/data/ad/ad387. pdf. Accessed Nov 1, 2007.

16. Westfall JM, Mold J, Fagnan L. Practice-based research-"Blue Highways" on the NIH roadmap. JAMA. 2007;297(4):403-406.

17. National Institutes of Health. NIH roadmap for medical reseachoverview of the NIH roadmap. http://nihroadmap.nih.gov/overview. asp. Accessed Jun 5, 2007.

18. Zerhouni EA, Alving B. Clinical and Translational Science Awards: a framework for a national research agenda. Transl Res. 2006; 148(1):4-5.

19. National Institutes of Health Reform Act of 2006. Pub L 109-482, HR 6164. http://olpa.od.nih.gov/legislation/109/publiclaws/reformact06.asp. Accessed Aug 15, 2007.

20. National Institutes of Health. Web site. http://www.nih.gov/icd/ index.html. Accessed Jun 5, 2007.

21. Rabinowitz HK, Becker JA, Gregory ND, Wender RC. NIH funding in family medicine: an analysis of 2003 awards. Ann Fam Med. 2006;4(5):437-442.

22. FY 2003 omnibus bill completes NIH doubling plan; large increases for bioterrorism RED and facilities. AAAS Funding Update. February $25,2003$.

23. National Institutes of Health. Activity codes, organizational codes, and definitions used in extramural programs-IMPAC (Information for Management, Planning, Analysis, and Coordination). July 2007. http://grants1.nih.gov/grants/funding/ac.pdf.

24. National Institutes of Health. NIH research grant awards by fiscal year and activity fiscal years 2002-2006. http://grants1.nih.gov/ grants/award/research/rgbyact0206.htm. Accessed Oct 10, 2007.

25. National Institutes of Health. Office of Federal Advisory Committee Policy. Web site. http://www1.od.nih.gov/cmo/about/index.html. Accessed Jun 12-Jun 25, 2007.
26. Zerhouni EA. Research funding. NIH in the post-doubling era: realities and strategies. Science. 2006;314(5802):1088-1090.

27. National Institues of Health. Number and total award amount of all NIH competing and noncompeting research grants by $\mathrm{NIH}$ Institute/Center FY 2007-2004. http://grants.nih.gov/grants/award/ Research/All_Research_By_IC.xls. Accessed Feb 6, 2008.

28. National Institues of Health. NIH research grant awards by grant mechanism and activity FY 2007-2002. http://grants.nih.gov/grants/ award/Research/RG_By_Mechanism_2007-2002.xls. Accessed Feb 6, 2008.

29. Dickler HB, Fang D, Heinig SJ, Johnson E, Korn D. New physicianinvestigators receiving National Institutes of Health research project grants: a historical perspective on the "endangered species". JAMA. 2007;297(22):2496-2501

30. National Institues of Health. Number of total award amounts of all NIH competing and noncompeting research grants by grant mechanism and activity code - FY 2007-1999. http://grants1.nih. gov/grants/award/research/Research_By_Activity_Code.xls. Accessed Feb 1, 2007.

31. National Institues of Health. NIH awards to medical schools by rank-fiscal year 2005. http://grants.nih.gov/grants/award/rank/ medttl05.htm.

32. Green LA, Fryer GE Jr, Yawn BP, Lanier D, Dovey SM. The ecology of medical care revisited. N Engl J Med. 2001;344(26):2021-2025.

33. Green LA, Dodoo MS, Ruddy G, et al. The physician workforce of the United States-a family medicine perspective. October; http:// www.graham-center.org/PreBuilt/physician_workforce.pdf.

34. Lucan SC, Barg FK, Bazemore AW, Phillips RoL. Family medicine, the NIH, \& the medical-research Roadmap: perspectives from inside NIH. Fam Med. In press.

35. National Institutes of Health. Selection criteria for NIH advisory committees. http://www1.od.nih.gov/cmo/committee/SelectionCriteria2007.pdf. Accessed August 6, 2007.

36. Hueston WJ. Research activity in family medicine: the "best of times" or "can I have more, please"? J Am Board Fam Med. 2008;21(1):4-5.

37. Hueston WJ, Mainous AG III. Family medicine research in the community setting: what can we learn from successful researchers? J Fam Pract. 1996;43(2):171-176.

38. Lindbloom EJ, Ewigman BG, Hickner JM. Practice-based research networks: the laboratories of primary care research. Med Care. 2004;42(4)(Suppl):III45-III49.

39. Kirch DG. AAMC President's Address 2007. Culture and Courage to Change. Paper presented at: Association of American Medical Colleges 118th Annual Meeting, Washington, DC; Nov 4, 2007.

40. Dougherty D, Conway PH. The " $3 T^{\prime}$ 's" road map to transform US health care: the "how" of high-quality care. JAMA. 2008;299(19):2319-2321.

41. Curtis $P$, Dickinson $P$, Steiner J, Lanphear B, Vu K. Building capacity for research in family medicine: is the blueprint faulty? Fam Med. 2003;35(2):124-130.

42. Health Resources and Services Administration (HRSA). Advisory Committee On Training in Primary Care Medicine and Dentistry Comprehensive Review and Recommendations: Title VII, Section 747 of The Public Health Service Act - Report to Secretary of the U.S. Department of Health and Human Services, and Congress November 2001. http://bhpr.hrsa.gov/medicine-dentistry/actpcmd/ report2001.htm\#AppA. Accessed Mar 12, 2008.

43. van Weel C, Rosser WW. Improving health care globally: a critical review of the necessity of family medicine research and recommendations to build research capacity. Ann Fam Med. 2004;2(Suppl 2): S5-S16

44. Martin JC, Avant RF, Bowman MA, et al. The future of family medicine: a collaborative project of the family medicine community. Ann Fam Med. 2004;2(Suppl 1):S3-S32. 